\title{
Urinary Insulin-Like Growth Factor-II Excretion in Healthy Infants and Children with Normal and Abnormal Growth ${ }^{1}$
}

\author{
TERESA QUATTRIN, CHRISTINE H. ALBINI, CARL SPORTSMAN, BARBARA J. SHINE, AND \\ MARGARET H. MACGILLIVRAY
}

Children's Hospital of Buffalo, Department of Pediatric's /T.Q., C.H.A., B.J.S., M.H.M.J State University' of New' York at Buffalo, Buffalo. New York 14222, and Lilly Research Laboratories /C.S./, Indianapolis, Indiana 46285

\begin{abstract}
The output of urinary IGF-II was measured by RIA in 12-h overnight urine samples obtained from 22 preterm and 15 full-term infants, 40 normal children, 18 children with growth hormone (GH) deficiency, and 25 patients with idiopathic short stature. GH deficiency was defined as a peak to $\mathrm{GH}$ provocative tests $\leq 9.9 \mu \mathrm{g} / \mathrm{L}$ during two provocative tests. The authenticity of urinary IGF-II was confirmed by size exclusion chromatography. Statistical analysis was performed by one-way analysis of variance using the Student Neuman-Keuls test to detect intergroup differences at the level of $p<0.05$. The preterm and full-term infants excreted significantly higher amounts of urinary IGF-II $(18.4 \pm 1.7$ and $5.7 \pm 1.0 \mathrm{pmol} / \mathrm{kg}$, respectively) compared with normal children $(2.4 \pm 0.25 \mathrm{pmol} /$ $\mathrm{kg} ; p<0.001)$. The output of urinary IGF-II in preterm infants was greater than that observed in full-term infants $(F=84.7, p<0.001)$. The control children excreted significantly more IGF-II $(2.4 \pm 0.2 \mathrm{pmol} / \mathrm{kg})$ than children with $\mathrm{GH}$ deficiency $(0.9 \pm 0.1 \mathrm{pmol} / \mathrm{kg})$ or idiopathic short stature $(1.0 \pm 0.1 \mathrm{pmol} / \mathrm{kg} ; F=13.5 ; p<0.001)$. Analysis of urinary IGF-II excretion based on creatinine output yielded similar results. Data on urinary IGF-I and GH previously published were correlated and compared with the excretion pattern of urinary IGF-II. Urinary GH correlates with urinary IGF-II in groups 3,4 , and $5(0.58$ and 0.46 per body weight and nmol of creatinine, respectively; $p<0.01$ ), as well as in the preterm and full-term infants $(0.51, p<0.01 ; 0.54, p<0.01)$ when the data were standardized for $\mathrm{kg}$ of body weight and $\mathrm{nmol}$ of creatinine, respectively. Children with GH deficiency excrete significantly less IGF-II compared with control subjects. This pattern is similar to that of urinary IGF-I. The highest urinary IGF-II output is observed in preterm infants, possibly reflecting a period of persistent elevation of IGF-II secondary to the young gestational age of these infants. (Pediatr Res 34: 435-438, 1993)
\end{abstract}

\section{Abbreviations}

\section{GH, growth hormone}

The influence of IGF-II on somatic growth of infants and children is still unclear. However, IGF-Il appears to play a primary role in prenatal growth, based on experiments that

Received February 3, 1993; accepted May 14. 1993.

Correspondence and reprint requests: Teresa Quattrin. M.D., Children's Hospital of Buffalo, 319 Bryant Street, Buffalo, NY 14222.

' Presented in part as a poster at the Endocrine Society, Washington, DC. June $19-22,1991$ showed growth retardation in fetal animals bearing an IGF-Il gene mutation (1). We previously have reported that urinary IGF-I is significantly higher in infants compared with children $(2,3)$, and the urinary excretion of IGF-I is significantly lower in children with GH deficiency and rises after GH treatment (4). Children with idiopathic short stature also have low urinary IGFI output compared with control subjects, but the degree of overlapping values in the two groups suggests that children with idiopathic short stature comprise a heterogeneous population (4). When plasma IGF-I and IGF-II were measured in normal children, only $0.5 \%$ of control subjects had low plasma levels of both IGF-I and IGF-II (5). However, the wide normal range for age of plasma IGF-I and IGF-II levels has made the use of either parameter in the diagnosis of $\mathrm{GH}$ deficiency difficult. There are no previous data on the quantitation of IGF-II in urine of healthy controls or subjects with GH deficiency.

The aim of this study was to quantitate and compare the urinary excretion of IGF-II in healthy growing preterm and fullterm infants and children with normal and abnormal growth. Also, we analyzed the excretion of both urinary IGF-I and IGFII to determine whether the simultaneous measurement of these peptides can better discriminate children with GH deficiency or idiopathic short stature from normal subjects. The data on urinary IGF-I have been previously published (2-4).

\section{MATERIALS AND METHODS}

We studied 22 preterm infants $(43.1 \pm 7.2 \mathrm{~d}$, group 1$), 17$ fullterm infants $(1.8 \pm 0.2 \mathrm{~d}$, group 2$), 40$ normal children $(9.5 \pm$ $0.6 \mathrm{y}$, group 3$), 15$ children with $\mathrm{GH}$ deficiency $(11.2 \pm 0.5 \mathrm{y}$, group 4), and 24 children with idiopathic short stature (12.8 \pm $0.6 \mathrm{y}$, group 5) (Table 1). The gestational age and corrected gestational age of the preterm infants were $30.3 \pm 0.8$ and 36.1 $\pm 0.5 \mathrm{wk}$, respectively. The children with $\mathrm{GH}$ deficiency and idiopathic short stature were followed at the endocrine clinic of the Children's Hospital of Buffalo. All were growing at a pathologic rate for age (less than $4.0 \mathrm{~cm} / \mathrm{y}$ ) and had a height lower than 2 SD from the mean. The height measurements were performed by trained personal using a Harpendon stadiometer (Holtein Limited). The tests used to diagnose GH deficiency were $\mathrm{L}$-arginine $(0.5 \mathrm{mg} / \mathrm{kg})$ and insulin-induced $(0.1 \mathrm{U} / \mathrm{kg})$ hypoglycemia, or L-dopa administration $(125 \mathrm{mg},<15 \mathrm{~kg}$ body weight; $250 \mathrm{mg}, 15$ to $30 \mathrm{~kg} ; 500 \mathrm{mg}$, $>30 \mathrm{~kg}$ ). The children diagnosed with $\mathrm{GH}$ deficiency had a peak $\mathrm{GH} \leq 9.9 \mu \mathrm{g} / \mathrm{L}(5.5 \pm$ $0.6)$ during two of the above stimulation tests. Idiopathic short stature was diagnosed when the children had a peak $\mathrm{GH}$ to stimulation test $\geq 10.0 \mu \mathrm{g} / \mathrm{L}(15.7 \pm 1.0)$. The group of normal children was composed of healthy volunteers who had height within 2 SD from the mean and were growing at a normal rate. Most of the infants and control groups in this study were composed of children included in our earlier studies (2-4). These 
Table 1. Clinical and demographic data of study population*

\begin{tabular}{lcccccc}
\multicolumn{1}{c}{ Group } & \multicolumn{2}{c}{$\begin{array}{c}\text { Sex } \\
\text { (M/F) }\end{array}$} & Age & $\begin{array}{c}\text { Height } \\
\text { (SD units) }\end{array}$ & $\begin{array}{c}\text { Weight } \\
\text { (SD units) }\end{array}$ & $\begin{array}{c}\text { Tanner stage } \\
\text { (prepubertal/pubertal) }\end{array}$ \\
\hline 1. Preterm infants & 22 & $10 / 12$ & $43.4 \pm 7.2 \mathrm{~d}$ & & & \\
2. Full-term infants & 17 & $9 / 8$ & $1.8 \pm 0.2 \mathrm{~d}$ & & & $26 / 14$ \\
3. Healthy controls & 40 & $22 / 18$ & $9.6 \pm 0.6 \mathrm{y}$ & $1.1 \pm 0.2$ & $0.8 \pm 0.2$ & $14 / 1$ \\
4. GH deficient & 15 & $11 / 4$ & $11.2 \pm 0.5 \mathrm{y}$ & $-1.9 \pm 0.1$ & $-0.5 \pm 0.2$ & $13 / 11$ \\
5. Idiopathic short stature & 24 & $20 / 4$ & $12.8 \pm 0.6 \mathrm{y}$ & $-2.6 \pm 0.2$ & $-1.2 \pm 0.1$ & \\
\hline * Data presented as mean \pm SEM. & & & &
\end{tabular}

* Data presented as mean \pm SEM.

children and their parents were all highly motivated to participate in the study and to perform the urine collection correctly. The clinical and demographic data of the population studied are presented in Table 1 . The research protocol was approved by the review board at our institution, and all parents gave written informed consent for their child's participation. None of the infants' prenatal histories were positive for maternal drug use during pregnancy or gestational diabetes. There was no clinical or laboratory evidence of intrauterine infection. All participants had normal urinalyses.

In the infants (groups 1 and 2), urine samples were collected for a 12-h period during either the day or night by means of a plastic urine bag, which was emptied periodically by the nursing staff. All diapers were weighed to validate the completeness of the collection. If a sample was contaminated by stools, the previous urine samples were discarded and the collection process was restarted. In the control group (group 3), urine samples were collected under parental supervision at home during a 12 -h overnight period $(2000$ to $0800 \mathrm{~h})$. The parents received detailed instructions. In the two groups with short stature (groups 4 and $5)$, the urine samples were collected in the hospital overnight before administration of the $\mathrm{GH}$ provocative tests.

The urine samples were kept refrigerated at $4^{\circ} \mathrm{C}$ throughout the collection period. Each urine sample was centrifuged to remove particulate matter and either dialyzed immediately or stored at $-20^{\circ} \mathrm{C}$ for later dialysis. Details on the dialysis and lyophilization procedures have been previously published (2-4). The urine concentrates were extracted using a formic acidacetone extraction developed at Eli Lilly (Indianapolis, IN) by Bowsher et al. (6). Formic acid $(50 \mu \mathrm{L}, 8 \mathrm{M})$ and $350 \mu \mathrm{L}$ of acetone were added to $100 \mu \mathrm{L}$ of sample in a polypropylene tube. After vortexing, the samples were centrifuged $(3000 \mathrm{rpm})$ for 20 min at $4^{\circ} \mathrm{C}$ and the supernatant was aspirated. The supernatant was diluted 10-fold with assay buffer. Urinary IGF-II was measured in duplicate by RIA using an assay developed at Lilly Research Laboratories (Indianapolis, IN) for determination of plasma IGF-II. The assay was validated for the determination of IGF-II urinary values. The intra-assay and interassay coefficients of variation for the RIA were 6.5 and $9.6 \%$, respectively. The slope of the four-parameters logistic fit was $1.1 \pm 0.1$ (mean \pm SD). The midrange of the assay was 1.0 to $1.4 \mathrm{ng} / \mathrm{mL}(0.13$ to $0.19 \mathrm{nmol} / \mathrm{L})$, with a minimum detectable concentration of 0.19 $\mathrm{ng} / \mathrm{mL}(0.03 \mathrm{nmol} / \mathrm{L})$. The assay uses an anti-IGF-II MAb from Amano Pharmaceutical (Troy, VA). Specificity data supplied by Amano Pharmaceutical indicate that bovine insulin and human epidermal growth factor do not cross-react with the antibody, whereas a $10 \%$ cross-reactivity with human IGF-I was found. The radiolabeled IGF-II ( ${ }^{125}$ I-IGF-II) was provided by Lilly. Recovery of added recombinant IGF-II $(2.5$ to $10.0 \mathrm{ng})$ was 82 to $93 \%$ (Table 2). Serial dilutions (1:5 to 1:40) of the urine concentrates confirmed linearity (Table 3 ).

Size-exclusion chromatography on Superose 12 was performed on extracted urine concentrates. The Superose 12 column $(1 \times$ $30 \mathrm{~cm})$ was equilibrated with a phosphate buffer $(0.01 \mathrm{M}$ sodium phosphate, $0.14 \mathrm{M} \mathrm{NaCl}, 0.01 \%$ sodium azide, $0.05 \%$ Tween $20, \mathrm{pH} 7.2$ ) at a flow rate of $0.5 \mathrm{~mL} / \mathrm{min}$. Standard proteins were dissolved in the phosphate buffer. The samples were prepared by formic acid-acetone extraction: $200 \mu \mathrm{L}$ of $8 \mathrm{M}$ formic acid/0.5\% Tween 20 were added to $400 \mu \mathrm{L}$ of the sample, which was subsequently vortexed. After having added $1400 \mu \mathrm{L}$ acetone, the sample was vortexed and centrifuged for $15 \mathrm{~min}$ at $3500 \mathrm{rpm}$; $1800 \mu \mathrm{L}$ supernatant then were added to a second tube containing $400 \mathrm{mg}$ BSA and a neutralizing amount of Tris base. The sample was dried on a speed-vac concentrator and then reconstituted in $400 \mu \mathrm{L}$ of water before $200 \mu \mathrm{L}$ were injected on the HPLC. Detection was performed by absorbance at $280 \mathrm{~nm}$ and by collecting 1-min fractions at the detector outlet for IGF-II RIA.

Urinary creatinine was measured using the Jaffe method. The data, expressed as mean $\pm S E M$, were standardized for $\mathrm{kg}$ of body weight and mol of creatinine. Statistical analysis was performed by one-way analysis of variance using the Student-Neuman-Keuls test to detect intergroup differences at the level of $p$ $<0.05$.

\section{RESULTS}

The data on urinary IGF-II excretion in the preterm infants (group 1), full-term infants (group 2), normal children (group 3), children with GH deficiency (group 4), and children with idiopathic short stature (group 5) are shown in Table 4. The preterm and full-term infants secreted a significantly higher amount of IGF-II [ $18.4 \pm 1.7 \mathrm{pmol} / \mathrm{kg}(137.9 \pm 12.5 \mathrm{ng} / \mathrm{kg})$ and $5.7 \pm 1.0$ $\mathrm{pmol} / \mathrm{kg}(42.8 \pm 7.7 \mathrm{ng} / \mathrm{kg})$, respectively] compared with the normal children $[2.4 \pm 0.25 \mathrm{pmol} / \mathrm{kg}(18.0 \pm 1.9 \mathrm{ng} / \mathrm{kg}), F=$ $84.7, p<0.001]$. The output of urinary IGF-II in the preterm infant group was significantly higher than that excreted by the full-term babies $(F=84.7, p<0.001)$. The control children excreted significantly more urinary IGF-Il output $[2.4 \pm 0.2$ $\mathrm{pmol} / \mathrm{kg}(18.0 \pm 1.9 \mathrm{ng} / \mathrm{kg})]$ than the children with $\mathrm{GH}$ deficiency or idiopathic short stature $[0.9 \pm 0.1 \mathrm{pmol} / \mathrm{kg}(8.0 \pm 1.5$ $\mathrm{ng} / \mathrm{kg})$ and $1.0 \pm 0.1 \mathrm{pmol} / \mathrm{kg}(7.43 \pm 1.0 \mathrm{ng} / \mathrm{kg})$, respectively; $F=13.5 ; p<0.001]$.

Figure 1 shows the chromatographic profile of an extracted urine sample applied to Superose 12 column. IGF-II immunoreactivity peaks at the position were authentic IGF-II elutes.

Analysis of urinary IGF-II excretion based on creatinine output $\mathrm{nmol} / \mathrm{g}$ of creatinine) yielded results comparable to those based on body weight: Preterm and full-term infants secreted significantly higher amounts of both peptides $(437.5 \pm 58.1$ and $128.4 \pm 32.0 \mathrm{nmol} / \mathrm{mol}$ creatinine, respectively) compared with normal children $(33.2 \pm 3.8 \mathrm{nmol} / \mathrm{mol}$ creatinine; $F=63.3 ; p<$ $0.001)$. Also, a significant difference was observed between the latter group and children with $\mathrm{GH}$ deficiency or idiopathic short stature $(12.9 \pm 2.0$ and $15.2 \pm 2.0 \mathrm{nmol} / \mathrm{mol}$ creatinine, respectively; $F=9.5 ; p<0.001$; Table 2 ). The data on the urinary output of GH and IGF-I have been previously published (2-4). A significant correlation was observed between the urinary output of IGF-I and IGF-II in children with normal and short stature (groups 3, 4, and 5) when data were standardized by either body weight or mol of creatinine $(r=0.60$ and 0.38 , respectively; $p<0.001$ ). In our previous work, we reported a positive correlation between IGF-I and GH urinary output (2). The latter correlates also with IGF-II in groups 3, 4, and $5(r=$ 0.58 and 0.46 per body weight and $g$ of creatinine, respectively). Also, in the preterm and full-term infants, a positive correlation was found between urinary GH and IGF-II $(r=0.51$ and 0.54 , $p<0.01$ ) when the data were standardized for $\mathrm{kg}$ of body weight 
Table 2. Experiments of recovery of IGF-II in spiked urine*

\begin{tabular}{|c|c|c|c|c|c|c|}
\hline & $\begin{array}{l}\text { IGF-II RIA } \\
\text { result } \\
(\mathrm{ng} / \mathrm{mL})\end{array}$ & $\begin{array}{l}\text { Expected } \\
\text { value } \\
(\mathrm{ng} / \mathrm{mL})\end{array}$ & $\begin{array}{c}\% \\
\text { Recovery }\end{array}$ & $\begin{array}{c}\text { IGF-II RIA } \\
\text { result } \\
(\mathrm{ng} / \mathrm{mL}) \\
\end{array}$ & $\begin{array}{c}\text { Expected } \\
\text { value } \\
(\mathrm{ng} / \mathrm{mL})\end{array}$ & $\begin{array}{c}\% \\
\text { Recovery }\end{array}$ \\
\hline Blank urine & 0.48 & & & 0.90 & & \\
\hline \multicolumn{7}{|l|}{ Spiked urine (ng) } \\
\hline+2.5 & 2.44 & 2.98 & 82 & 3.0 & 3.4 & 88 \\
\hline+5.0 & 5.10 & 5.48 & 93 & 5.3 & 5.9 & 90 \\
\hline+10.0 & 9.10 & 10.48 & 87 & 10.1 & 10.9 & 93 \\
\hline
\end{tabular}

* Conversion factor for IGF-Il to $\mathrm{nmol} / \mathrm{L}$ is 0.1333 .

Table 3. Experiment of serial dilution of urine sample*

\begin{tabular}{lcc}
\hline \multicolumn{1}{c}{ Sample } & $\begin{array}{c}\text { IGF-II } \\
(\mathrm{ng} / \mathrm{mL})\end{array}$ & $\begin{array}{c}\text { Expected } \\
\text { value }(\mathrm{ng} / \mathrm{mL})\end{array}$ \\
\hline $\begin{array}{l}\text { Undiluted } \\
\text { Diluted }\end{array}$ & 12.3 & \\
$1: 2$ & & \\
$1: 5$ & 6.0 & 6.15 \\
$1: 10$ & 2.39 & 2.46 \\
$1: 20$ & 1.20 & 1.23 \\
$1: 40$ & 0.64 & 0.61 \\
\hline
\end{tabular}

* Conversion factor for IGF-II to $\mathrm{nmol} / \mathrm{L}$ is 0.1333

Table 4. $I G F-I^{*}$

\begin{tabular}{lcc}
\hline \multicolumn{1}{c}{ Group } & $\begin{array}{c}\text { IGF-II } \\
(\mathrm{pmol} / \mathrm{kg})\end{array}$ & $\begin{array}{c}\text { IGF-II } \\
(\mathrm{nmol} / \mathrm{mol} \text { creatinine })\end{array}$ \\
\hline 1. Preterm infants & $18.4 \pm 1.7 \dagger \ddagger$ & $437.5 \pm 58.1 \dagger \ddagger$ \\
2. Full-term infants & $5.7 \pm 1.0 \dagger \ddagger$ & $128.4 \pm 32.0 \dagger \ddagger$ \\
3. Healthy controls & $2.4 \pm 0.2 \dagger \ddagger$ & $33.2 \pm 3.8 \dagger \ddagger$ \\
4. GH deficient & $0.9 \pm 0.1 \S$ & $12.9 \pm 2.0 \S$ \\
5. Idiopathic short stature & $1.0 \pm 0.1 \S$ & $15.2 \pm 2.0 \S$ \\
\hline
\end{tabular}

* Values are mean \pm SEM.

+ Group 3 is significantly lower than either group 1 or $2 ; p<.05$.

$\ddagger$ Group 2 is lower than group $1 ; p<.05$.

$\S$ Group 3 is significantly higher than either group 4 or $5 ; p<.05$.

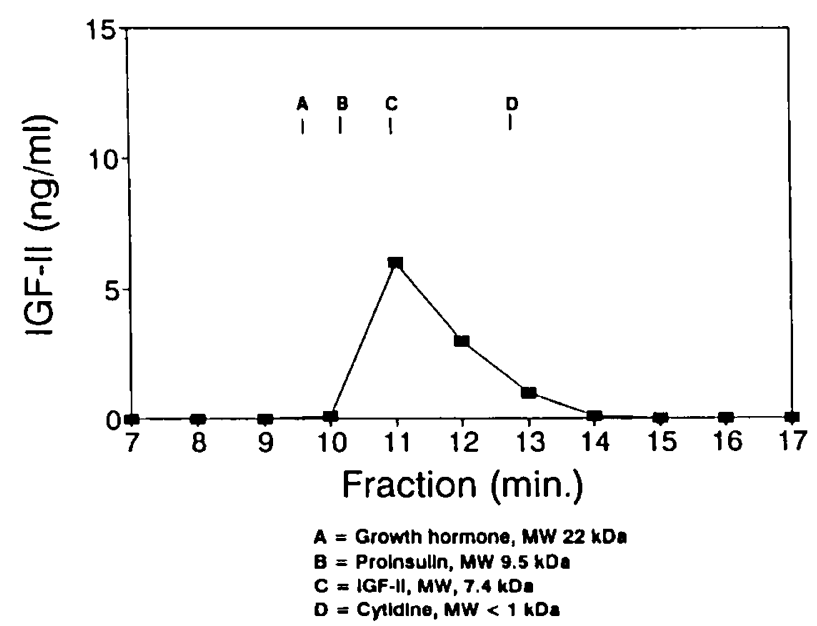

Fig. 1. Chromatographic profile of extracted urine sample. IU conversion factor from $\mathrm{ng} / \mathrm{mL}$ to $\mathrm{nmol} / \mathrm{L}$ is 0.1333 .

and creatinine (nmol), respectively. In the preterm group, an inverse correlation was found between corrected gestational age and urinary IGF-II output $(-0.70, p<0.001)$ when data were standardized by $\mathrm{kg}$ of body weight.

\section{DISCUSSION}

Our data show that the urinary output of IGF-II is significantly greater in infants compared with children, similar to the relationship previously observed for the urinary excretion of IGF-I in these two populations (2-4). Based on body weight or $\mathrm{g}$ of creatinine, the urinary output of IGF-II is significantly greater in preterm than in full-term infants. This pattern is different from the IGF-I excretion in that no significant difference was previously observed in the output of IGF-I between full-term and preterm infants $(2,3)$. In light of the role played by IGF-II in prenatal growth, the higher IGF-II output observed in preterm compared with full-term infants, may reflect a period of persistent IGF-II elevation due to the younger gestational age of these infants. The significant elevation of both urinary IGF-II and IGF-I, the latter previously documented, observed in infants compared with children is consistent with the rapid growth rate during infancy $(2,3,7)$. Therefore, it is possible that both IGF-I and IGF-II are important growth mediators early in life. We have previously reported the significant elevation of urinary IGFI in healthy full-term and preterm infants in the presence of low circulating levels of this peptide. Urinary IGF-II values correlate with urinary GH as well. Whereas the significant association observed between urinary values of IGF-I and GH output supports the somatomedin hypothesis $(2,8,9)$, the clinical significance of the correlation between GH and IGF-II is unclear. As previously reported for urinary IGF-I, the origin of urinary IGFII remains to be clarified. Although several studies have proven that IGF-I is produced at multiple sites and possesses an autocrine-paracrine as well as an endocrine mode of action, less is known about IGF-II $(10,11)$. It is possible that urinary IGF-II represents filterable plasma IGF-II or possibly synthesis and excretion of this peptide by the kidney because IGF-II is present in abundant concentrations in the human kidney $(12,13)$. If urinary IGF-II were proven to be only renal in origin, the correlation existing between urinary IGF-II and GH could be due to IGF-II regulation by renal GH receptors.

There are conflicting opinions as to whether IGF-I in urine is present in free form or bound to binding protein $(2,14,15)$. Our previous studies indicate that although most of the IGF-I in urine is unbound, a small fraction is complexed to a binding protein (2). We have not determined whether IGF-II in urine is also predominantly unbound, but believe a relationship similar to IGF-I exists. Regardless of this question, the authenticity of IGFII has been confirmed by size-exclusion chromatography. $\mathrm{Hy}$ pothetically, the quantitation of IGF in urine may be more reliable because it represents an integrated measurement. and the content of binding protein is lower in urine than in plasma $(16,17)$.

We previously have addressed the potential problem of renal immaturity causing a higher urinary output of IGF (3). As previously observed in the urinary IGF-I excretion, no correlation was found between $\beta_{2}$ microglobulin and urinary IGF-II output. The data on $\beta_{2}$ microglobulin have been previously published (3).

Children with GH deficiency or idiopathic short stature exhibit a pattern of urinary IGF-II excretion similar to that previously reported for IGF-I and GH output, i.e. the mean urinary IGF-II output is significantly lower in short children compared with control subjects (4). However, overlap among the groups suggests that the isolated determination of urinary IGF-II would not differentiate children with GH deficiency or idiopathic short stature from normal subjects. Also, the simultaneous measure- 
ment of both peptides does not increase substantially the specificity of the screening test.

In conclusion, the overlap of urinary IGF-I and IGF-II values, more marked between controls and children with idiopathic short stature, strongly limits their usefulness as a screening and diagnostic tool. Because children with idiopathic short stature have a normal response to $\mathrm{GH}$ stimulation tests, a decision about $\mathrm{GH}$ therapy in this population must be based on their height and growth rate.

Acknowledgments. The authors thank Mary Jane Lannen for help with manuscript preparation.

\section{REFERENCES}

1. DeChiara TM. Efstratiadis A, Robertson EJ 1990 A growth-deficiency phenotype in heterozygous mice carrying an insulin-like growth factor II gene disrupted by targeting. Nature 345:78-80

2. Quattrin T, Albini CH, Cara JF, Vandlen RL, Mills BJ, MacGillivray MH 1988 Quantitation of urinary somatomedin-C and growth hormone in preterm and fullterm infants and normal children. J Clin Endocrinol Metab 66:792-797

3. Quattrin T, Albini CH, Mills BJ, MacGillivray M 1990 Comparison of urinary growth hormone and IGF-I excretion in small- and appropriate-for-gestational-age infants and healthy children. Pediatr Res 28:209-212

4. Quattrin T, Albini CH, Vandlen RL, MacGillivray M 1987 Quantitation of urinary somatomedin-C in children with normal and abnormal growth. $J$ Clin Endocrinol Metab 65:1168-1171

5. Rosenfeld RG, Wilson DM. Lee PDK, Hintz RL 1986 Insulin-like growth factors I and II in evaluation of growth retardation. J Pediatr 109:428-433
6. Bowsher RR, Lee WH. Apathy JM, O'Brien PJ, Ferguson AL, Henry DP 1991 Measurement of IGF-II in physiological fluids and tissue. Improved extraction procedure and radioimmunoassay for human and rat fluids. Endocrinology 128:805-814

7. Quattrin T, Albini CA, Milis BJ, Sportsman RJ 1991 Low urinary IGF-I and IGF-II excretion in children with GH deficiency and subjects with idiopathic short stature. The Endocrine Society, Abstract Book of the 73rd Annual Meeting. Washington. DC. June 19-22

8. Albini CH. Quattrin T, Vandlen RL. MacGillivray M 1988 Quantitation of urinary growth hormone in children with normal and abnormal growth. Pediatr Res 23:89-92

9. Daughaday WJ 1981 Growth hormone and the somatomedins. In: Daughaday WJ (ed) Endocrine Control of Growth. Elsevier. New York, p 1

10. D'Ercole AJ. Applewhite GT, Underwood LE 1980 Evidence that somatomedin is synthesized by multiple tissues in the fetus. Dev Biol 75:315-328

11. Daughaday W, Rotwein P 1989 Insulin-like growth factors 1 and II. Peptide, messenger ribonucleic acid and gene structures, serum, and tissue concentrations. Endocr Rev 10:68-91

12. D'Ercole AJ, Decedue CJ, Furlanetto RW, Underwood LE, Van Wyk JJ 1977 Evidence that somatomedin-C is degraded by the kidney and inhibits insulin degradation. Endocrinology 101:577-585

13. Chin E. Bondy C 1992 Insulin-like growth factor system gene expression in the human kidney. J Clin Endocrinol Metab 75:962-968

14. Hizuka N, Takano K. Tanaka I. Asakawa K. Miyakawa M. Horikawa R, Shizume K 1987 Demonstration of insulin-like growth factor $I$ in human urine. J Clin Endocrinol Metab 64:1309-1312

15. Cohen P. Fielder PJ. Hasegawa Y. Frisch H. Giudice LC, Rosenfeld RG 1991 Clinical aspects of insulin-like growth factor binding proteins. Acta Endocrinol (Copenh) 124:74-85

16. Baxter RC, Martin JL 1989 Binding proteins for the insulin-like growth factors: structure, regulation and function. Prog Growth Factor Res 1:49-68

17. Furlanetto RW. Underwood L, Van Wyk JJ. D'Ercole AJ 1977 Estimation of somatomedin-C levels in normals and patients with pituitary disease by radioimmunoassay. J Clin Invest 60:648-647 